\title{
A Convenient and Efficient Protocol for the One Pot Synthesis of 3,4-Dihydropyrimidin-2-(1H)-ones Catalyzed by Ionic Liquids under Ultrasound Irradiation
}

\author{
Abhishek N. Dadhania, Vaibhav K. Patel and Dipak K. Raval* \\ Department of Chemistry, Sardar Patel University, Vallabh Vidyanagar, 388 120, Gujarat, India
}

\begin{abstract}
Derivados de 3,4-dihidropirimidin-2-(1H)-onas foram sintetizados via uma reação one-pot de três componentes, com excelentes rendimentos em curtos tempos reacionais, usando aldeídos, acetoacetato de etila e uréia (ou tiouréia) em líquidos iônicos à temperatura ambiente (RTILs) sob radiação de ultrassom, sem adição de catalisador. Um mecanismo sintético plausível foi postulado levando em consideração o papel catalítico dos líquidos iônicos em promover a reação. Os líquidos iônicos puderam ser reciclados no mínimo seis vezes com boa retenção de atividade.
\end{abstract}

Derivatives of 3,4-dihydropyrimidin-2-(1H)-ones were synthesized in excellent yields in short reaction time by one pot, three component reaction of aldehydes, ethyl acetoacetate and urea (or thiourea) in room temperature ionic liquids (RTILs) under ultrasound irradiation without any added catalyst. A plausible mechanistic pathway has been postulated based on the catalytic role of the ionic liquid in promoting the reaction. The ionic liquids could be recycled at least six times with retention of their activity.

Keywords: one pot synthesis, 3,4-dihydropyrimidin-2-(1H)-ones, ionic liquid, ultrasound

\section{Introduction}

3,4-Dihydropyrimidin-2-(1H)-ones (DHPMs) and their derivatives have attracted global interest because of their pharmacological and therapeutic properties. ${ }^{1,2}$ They have emerged as integral backbones of several calcium channel blockers, antihypertensive agents, alpha-1a adrenergic receptor antagonists. ${ }^{3}$ Several marine alkaloids containing the DHPM unit have shown interesting biological properties. ${ }^{4}$ Synthetic strategies towards the dihydropyrimidine nucleus involve one-pot to multistep approaches. The classical synthesis of DHPM nucleus, condensation of ethyl acetoacetate, benzaldehyde and urea under strong acidic condition was low yielding (20-50\%). ${ }^{1}$ Subsequent multistep synthesis produced somewhat higher yields but lacked the simplicity of one-pot, one-step procedure. ${ }^{5}$ Consequently, for the synthesis of DHPMs many improved procedures have been reported. Many of these procedures effectively employed catalyst such as $\mathrm{BF}_{3} \cdot \mathrm{Et}_{2} \mathrm{O}^{6}$ in combination with transition metal salts and a proper proton source. Polyphosphate ester ${ }^{7}$ was claimed to greatly improve the yield. Recently, the use of various catalysts ${ }^{8}$ like polystyrene sulphonic acid (PSSA), $\mathrm{Bi}\left(\mathrm{NO}_{3}\right)_{3}, \mathrm{PhB}(\mathrm{OH})_{2}, \mathrm{TaBr}_{5}$,

*e-mail: dipanalka@yahoo.com acidic clay montmorillonite KSF, zeolites, $\mathrm{FeCl}_{3} \cdot 6 \mathrm{H}_{2} \mathrm{O}$, $\mathrm{LaCl}_{3} \cdot 7 \mathrm{H}_{2} \mathrm{O}, \mathrm{Yb}(\mathrm{OTf})_{3}, \mathrm{InCl}_{3}$ have been reported. In addition, microwave ${ }^{9}$ and ultrasound ${ }^{10}$ are also reported to promote the Biginelli three component cyclocondensation reaction. Most of the reported methods employ strong acidic conditions, high temperature and require long reaction times, or use expensive catalysts. From a literature survey, emerged the need to carry out this reaction with higher atom utilization and shorter reaction times under milder reaction conditions.

Ionic liquids (ILs) have attracted extensive research interest as environmental benign solvents due to their negligible vapour pressure, solvating ability, reusability and high thermal stability. ${ }^{11}$ Apart from this, some ILs possess inherent Lewis/Bronsted acidity; ${ }^{12}$ by combining these unique properties they have emerged as a "green reaction media". The use of ILs as reactions media may offer a convenient solution to both the solvent emission and catalytic recycling problem with high efficiency. ${ }^{13}$ The use of ultrasound is now well known to enhance the reaction rates and yields of reactions under milder conditions. ${ }^{14}$ The considerable energy for transformation is liberated by formation and collapse of bubbles. The reaction media such as ILs, having negligible vapour pressure, ${ }^{15}$ should change characteristics of cavitation and force less volatile 
substrates to undergo the cavitational activation. From this fact, we planned for further innovations in this multi component reaction (MCR) by practising sonochemistry in ILs. Proceeding on the same lines, we opted to evolve an efficient and ecofriendly process for the preparation of ionic liquid 1-carboxymethyl-3-methylimidazolium tetrafluoroborate $[\mathrm{cmmim}]\left[\mathrm{BF}_{4}\right]$ by ultrasound irradiation.

Herein we disclose the preparation of $[\mathrm{cmmim}]\left[\mathrm{BF}_{4}\right]$ via ultrasound and report the synthesis of DHPMs promoted by the combined use of ultrasound and the mixture of carboxy functionalized ionic liquid $[\mathrm{cmmim}]\left[\mathrm{BF}_{4}\right]$ and 1-butyl3-methylimidazolium tetrafluoroborate $[\mathrm{bmim}]\left[\mathrm{BF}_{4}\right]$ at $30{ }^{\circ} \mathrm{C}$ in excellent isolated yields. The mixture of ILs can be efficiently recovered and reused at least six times. The process holds well without any added catalyst.

\section{Results and Discussion}

Song and co-workers ${ }^{16}$ have reported the synthesis of $[\mathrm{cmmim}]\left[\mathrm{BF}_{4}\right]$ under conventional conditions at $70{ }^{\circ} \mathrm{C}$. Herein we have successfully carried out the same transformation under sonication at ambient temperature in comparatively shorter duration.

A variety of aldehydes were condensed with ethyl acetoacetate and urea (or thiourea) as shown in Scheme 1. Typical ultrasound assisted MCR of benzaldehyde, ethyl acetoacetate and urea was chosen as a model reaction for optimization. The results are shown in Table 1. Using [cmmim] $\left[\mathrm{BF}_{4}\right]$ as the sole solvent, the reaction system became non homogeneous and proceeded with comparatively low yield over a long reaction time, due to the low solvation capacity of IL (entry 1). Consequently, another ionic liquid was added as a co-solvent to increase the solvation capacity of the medium. With carboxyl-functionalized ionic liquid $\left[\mathrm{cmmim}^{-}\left[\mathrm{BF}_{4}\right]\right.$ in hand, various proportions with $[\mathrm{bmim}]\left[\mathrm{BF}_{4}\right]$ were screened for the model reaction to afford 5-ethoxycarbonyl-4-phenyl6-methyl-3,4-dihydropyrimidin-2-(1H)-one (Table 1). When the voluminal ratio of $[\mathrm{bmim}]\left[\mathrm{BF}_{4}\right]$ was increased (entry 2, 3 and 4) a ramp in the yields with shorter reaction time was observed. Based on that evidence the optimal ratio of $[\mathrm{cmmim}]\left[\mathrm{BF}_{4}\right]$ to $[\mathrm{bmim}]\left[\mathrm{BF}_{4}\right]$ was chosen to be $2: 1(\mathrm{v} / \mathrm{v})$. Based on this investigation, a number of DHPMs (Table 2, a-o) were successfully synthesized using the same proportion for IL mixture from variety of aldehydes. The reaction proceeded with low yield over a long reaction time when $[\mathrm{bmim}]\left[\mathrm{BF}_{4}\right]$ sole was employed as the reaction medium (Table 1, entry 5). From this observation, it becomes evident that the role of $[\mathrm{bmim}]\left[\mathrm{BF}_{4}\right]$ is as a co-solvent, the reaction does not get accelerated by its presence. A series of successful experiments were run by using molecular solvents like methanol and ethyl acetate as the co-solvents in lieu of $[\mathrm{bmim}]\left[\mathrm{BF}_{4}\right]$. To avoid the use of molecular solvents, we opted for $[\mathrm{bmim}]\left[\mathrm{BF}_{4}\right]$ as the co-solvent for the reaction.

Table 1. The effects of ratio between $[\mathrm{cmmim}]\left[\mathrm{BF}_{4}\right]$ and $[\mathrm{bmim}]\left[\mathrm{BF}_{4}\right]$ on the synthesis of $\mathbf{2} \mathbf{a}$ under ultrasound irradiation

\begin{tabular}{lccc}
\hline entry & $\begin{array}{c}{[\mathrm{cmmim}]\left[\mathrm{BF}_{4}\right]:} \\
{[\mathrm{bmim}]\left[\mathrm{BF}_{4}\right](\mathrm{v} / \mathrm{v})}\end{array}$ & $\begin{array}{c}\text { time / } \\
\min \end{array}$ & $\begin{array}{c}\text { Yield / } \\
(\%)^{\mathrm{a}}\end{array}$ \\
\hline 1 & $1: 0$ & 60 & 83 \\
2 & $3: 1$ & 55 & 90 \\
3 & $2: 1$ & 40 & 96 \\
4 & $1: 1$ & 50 & 92 \\
5 & $0: 1$ & 60 & 81 \\
\hline
\end{tabular}

asolated yield of $\mathbf{2 a}$.

Table 2. Different DHPMs synthesized by Condensation of aldehydes 1a-o with EAA and urea-thiourea in ionic liquid under ultrasonic irradiation

\begin{tabular}{|c|c|c|c|c|c|}
\hline Product 2 & $\mathrm{R}$ & $\mathrm{X}$ & $\begin{array}{c}\text { Ultrasound irradiation } \\
\text { time / min }\end{array}$ & $\begin{array}{l}\text { Yield / } \\
(\%)^{\mathrm{a}}\end{array}$ & $\begin{array}{c}\mathrm{mp} /{ }^{\circ} \mathrm{C} \\
\text { observed (lit.) }\end{array}$ \\
\hline $2 a$ & $\mathrm{Ph}-$ & $\mathrm{O}$ & 40 & 96 & $201-202(202-204)^{17}$ \\
\hline $2 b$ & $4-\mathrm{O}_{2} \mathrm{~N}-\mathrm{C}_{6} \mathrm{H}_{4}-$ & $\mathrm{O}$ & 65 & 97 & $206-208(207-209)^{18}$ \\
\hline $2 c$ & $4-\mathrm{F}-\mathrm{C}_{6} \mathrm{H}_{4}-$ & $\mathrm{O}$ & 55 & 94 & $174-176(175-176)^{20}$ \\
\hline 2d & $3-\mathrm{Cl}-\mathrm{C}_{6} \mathrm{H}_{4}-$ & $\mathrm{O}$ & 45 & 94 & $192-194(193-195)^{17}$ \\
\hline $2 e$ & $4-\mathrm{H}_{3} \mathrm{C}-\mathrm{C}_{6} \mathrm{H}_{4}-$ & $\mathrm{O}$ & 40 & 95 & $214-215(215-216)^{18}$ \\
\hline $2 f$ & 4- $\mathrm{MeO}-\mathrm{C}_{6} \mathrm{H}_{4}-$ & $\mathrm{O}$ & 45 & 97 & $200-202(202-204)^{17}$ \\
\hline $2 \mathrm{~g}$ & 2-Furyl- & $\mathrm{O}$ & 40 & 94 & $208-210(209-211)^{17}$ \\
\hline $2 \mathrm{~h}$ & $2-\mathrm{Cl}-\mathrm{C}_{6} \mathrm{H}_{4}-$ & $\mathrm{O}$ & 35 & 96 & $221-222(222-224)^{17}$ \\
\hline $2 \mathbf{i}$ & $4-\mathrm{HO}-\mathrm{C}_{6} \mathrm{H}_{4}-$ & $\mathrm{O}$ & 45 & 94 & $228-230(230-232)^{17}$ \\
\hline $2 \mathrm{j}$ & $3,4,5-(\mathrm{MeO})_{3}-\mathrm{C}_{6} \mathrm{H}_{2}-$ & $\mathrm{O}$ & 50 & 96 & $178-180(180-182)^{19}$ \\
\hline $2 \mathrm{k}$ & $4-\mathrm{HO}, 3-\mathrm{MeO}-\mathrm{C}_{6} \mathrm{H}_{3}-$ & $\mathrm{O}$ & 45 & 94 & $202-203(204-205)^{19}$ \\
\hline 21 & 2-Thienyl & $\mathrm{O}$ & 45 & 92 & $214-216(215-217)^{17}$ \\
\hline $2 \mathrm{~m}$ & $\mathrm{Ph}-$ & $\mathrm{S}$ & 50 & 91 & $207-208(208-210)^{17}$ \\
\hline $2 n$ & 4-MeO- $\mathrm{C}_{6} \mathrm{H}_{4}-$ & $\mathrm{S}$ & 55 & 94 & $150-151(150-152)^{17}$ \\
\hline 20 & $3,4,5-(\mathrm{MeO})_{3}-\mathrm{C}_{6} \mathrm{H}_{2}-$ & $\mathrm{S}$ & 70 & 91 & $201-203(202-204)^{21}$ \\
\hline
\end{tabular}

${ }^{a}$ Yields after recrystallisation. ${ }^{\mathrm{b}}$ Melting points are uncorrected. 


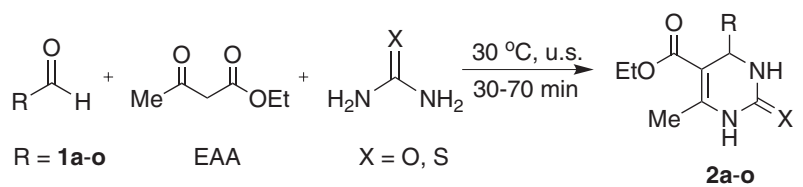

Scheme 1. Synthesis of 3,4-dihydropyrimidin-2(1H)-ones.

All the reactions were monitored by TLC and carried forward to maximum atom utilization. All the compounds were characterized by melting point, IR, ${ }^{1} \mathrm{H}$ NMR, ${ }^{13} \mathrm{C}$ NMR and mass spectral techniques. All the data were in agreement with the cited literature. It was noticed that the aldehydes having electron donating/withdrawing substituent reacted in short reaction time to afford the DHPMs in very good to excellent isolated yields.

From the experimental observations, it was noticed that the reactions did not proceed even after minutes of ultrasound irradiation in molecular solvents such as ethanol and ethyl acetate in place of the ILs. Similarly, formation of DHPMs was not observed when the reactions were conducted in the ILs under simple stirring at $30{ }^{\circ} \mathrm{C}$ without ultrasonic irradiation. Thus the combined use of ultrasound irradiation and the ionic liquid as reaction medium has promoted Biginelli reaction in absence of any added catalyst.

The IL $[\mathrm{cmmim}]\left[\mathrm{BF}_{4}\right]$ promotes the reaction due to its inherent Brønsted acidity. The $-\mathrm{COOH}$ proton of [cmmim] $\left[\mathrm{BF}_{4}\right]$ is capable of bonding with the aldehydic carbonyl oxygen of aldehyde as well as ketonic carbonyl oxygen of ethylacetoacetate as shown in Scheme 2. Evidence for this was obtained by recording ${ }^{13} \mathrm{C}$ NMR spectra of $p$-tolualdehyde (neat) and EAA (neat) with an external lock of $\mathrm{D}_{2} \mathrm{O}$. The results are shown in Table 3. When ${ }^{13} \mathrm{C}$ NMR spectra of neat $p$-tolualdehyde and EAA were recorded, the chemical shift for aldehydic and ketonic carbonyl carbon was observed respectively at 190.6 and $200.4 \mathrm{ppm}$. When ${ }^{13} \mathrm{C}$ NMR spectra of both the substrates were recorded with one equivalent of [cmmim] $\left[\mathrm{BF}_{4}\right]$ under similar conditions, no significant change was
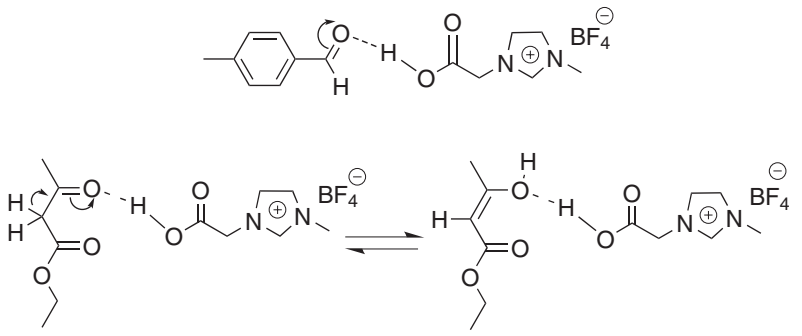

Scheme 2. Bonding of $-\mathrm{COOH}$ proton of $[\mathrm{cmmim}]\left[\mathrm{BF}_{4}\right]$ with aldehydic carbonyl oxygen of aldehyde and ketonic carbonyl oxygen of EAA.

observed in the chemical shifts of carbonyl carbon (only ca. $0.2 \mathrm{ppm}$ ), possibly due to the low solvation capacity of the IL. However, when the ${ }^{13} \mathrm{C}$ NMR spectra of both the substrates when recorded in a 2:1 mixture of $[\mathrm{cmmim}]\left[\mathrm{BF}_{4}\right]$ and $[\mathrm{bmim}]\left[\mathrm{BF}_{4}\right]$ under similar conditions, significant change in the chemical shifts were observed for aldehydic and ketonic carbonyl carbons ( $c a .5 \mathrm{ppm}$ ) for both due to their interaction with IL. A plausible mechanistic pathway has been postulated based on this evidence (Scheme 3).

Table 3. ${ }^{13} \mathrm{C}$ NMR chemical shifts for the formyl and ketonic carbonyl carbons of $p$-tolualdehyde and EAA

\begin{tabular}{|c|c|c|}
\hline entry & Substrate & $\begin{array}{c}\text { Chemical Shift }{ }^{\mathrm{a}}, \\
\delta / \mathrm{ppm}\end{array}$ \\
\hline 1 & & 190.6 \\
\hline 2 & $+[\mathrm{cr}$ & 190.8 \\
\hline 3 & $\begin{array}{l}+[\mathrm{cr} \\
+[\mathrm{br}\end{array}$ & 196.0 \\
\hline 4 & & 200.4 \\
\hline 5 & $+[\mathrm{cr}$ & 200.7 \\
\hline 6 & $\begin{array}{l}+[\mathrm{cr} \\
+[\mathrm{bl}\end{array}$ & 205.10 \\
\hline
\end{tabular}

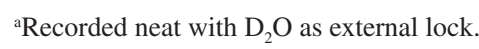

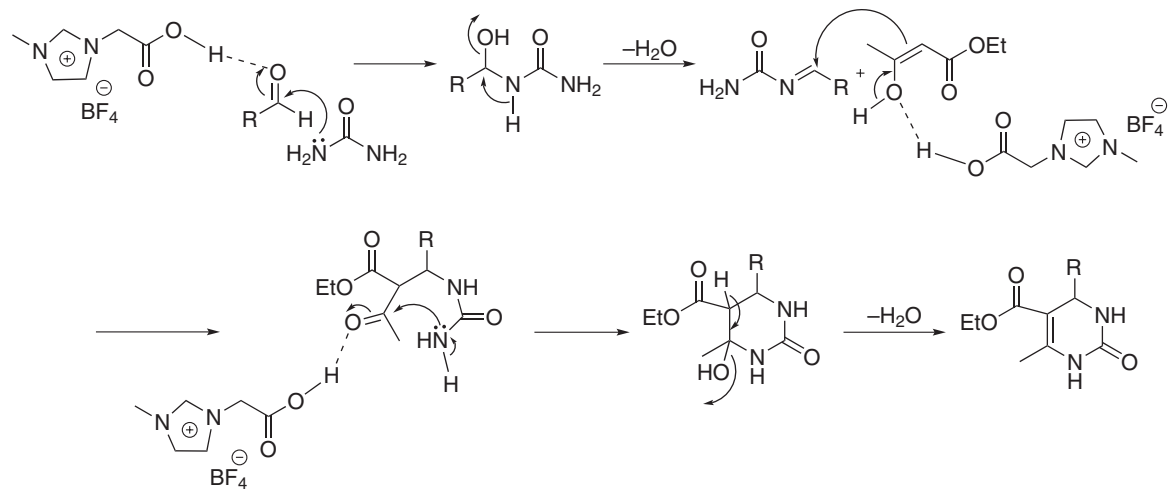

Scheme 3. Plausible mechanistic pathway for the reaction. 
The activity of recycled ionic liquid was studied in the synthesis of 2a. After product separation, the aqueous filtrate was subjected to vacuum for $\mathbf{4 h}$, to leave behind the mixture of ionic liquids. This mixture was reused in the next run without any further purification. As shown in Figure 1 the reaction medium can be reused for at least six times without significant decrease in the yields.

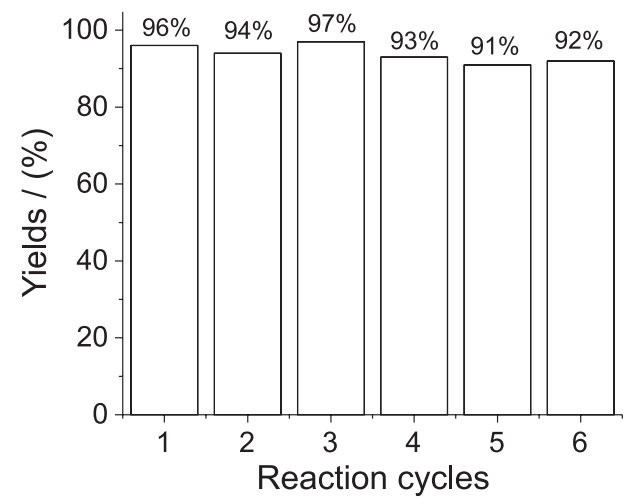

Figure 1. Recyclability of ionic liquid mixture.

\section{Experimental}

\section{Materials}

All chemicals were of research grade and were used as obtained. The reactions were performed in D-compact ultrasonic cleaner with a frequency of $50 \mathrm{kHz}$ and power 250 W. IR spectra were recorded on a FT IR Perkin Elmer Spectrum GX spectrometer, mass spectra on a Shimadzu GCMS QP 2010 instrument, elemental analysis on Perkin Elmer PE 2400 elemental analyzer and ${ }^{1} \mathrm{H}$ NMR and ${ }^{13} \mathrm{C}$ NMR spectra were recorded on Bruker Avance $400 \mathrm{MHz}$ spectrometer in $\mathrm{CDCl}_{3} / \mathrm{DMSO}_{-} d_{6}$ with TMS as an internal standard. The melting points are uncorrected and are compared with the reported literature values.

\section{Preparation of carboxyl-functionalized ionic liquid [cmmim] $\left[\mathrm{BF}_{4}\right]$}

Aliquots of chloroacetic acid ( 1 equiv.) was added over a period of $60 \mathrm{~min}$ to 1 -methyl-imidazole (1 equiv.) at room temperature under stirring, and then the reaction mixture was exposed to ultrasound for an additional period of $120 \mathrm{~min}$ at ambient temperature. The solid thus obtained was washed with acetonitrile, and dried under vacuum. The intermediate, 1-carboxymethyl-3methylimidazolium chloride was obtained as a white solid (mp 172-174 ${ }^{\circ} \mathrm{C}$ ). The [cmmim] [Cl] (1 equiv.) and $\mathrm{NaBF}_{4}$ (1 equiv.) were dissolved in $\mathrm{H}_{2} \mathrm{O}$ and exposed to ultrasound at $70{ }^{\circ} \mathrm{C}$ for $2.5 \mathrm{~h}$. Water was removed from the reaction mixture by subjecting it to evaporation for $4 \mathrm{~h}$ at $80^{\circ} \mathrm{C}$ under reduced pressure $(10 \mathrm{~mm} \mathrm{Hg})$ to give the product $[\mathrm{cmmim}]\left[\mathrm{BF}_{4}\right]$ as a slight yellowish oil. This was characterized by ${ }^{1} \mathrm{H}$ NMR and ${ }^{13} \mathrm{C}$ NMR. All the data were in good agreement with the reported method. ${ }^{1} \mathrm{H}$ NMR (400 MHz, $\left.\mathrm{D}_{2} \mathrm{O}\right): \delta 8.38(\mathrm{~s}, 1 \mathrm{H}), 7.11-7.12(\mathrm{~d}$, $J 1.6 \mathrm{~Hz}, 2 \mathrm{H}), 4.73(\mathrm{~s}, 2 \mathrm{H}), 3.55$ (s, 3H).

General procedure for the synthesis of DHPMs

A mixture containing aldehyde $\mathbf{1}(10 \mathrm{mmol})$, ethyl acetoacetate (EAA, $10 \mathrm{mmol}$ ) and urea or thiourea $(11 \mathrm{mmol})$ in the mixture of $\left[\mathrm{cmmim}_{[}\left[\mathrm{BF}_{4}\right]\right.$ and $[\mathrm{bmim}]\left[\mathrm{BF}_{4}\right](2: 1,2 \mathrm{~g})$ was exposed to ultrasound at $30^{\circ} \mathrm{C}$. The reactions were carried out in a $25 \mathrm{~mL}$ capacity round bottom flask. Reactant mixture was suspended at the center of the bath, slight below the water surface. At completion of the reaction (as indicated by TLC), a solid product gradually formed was poured into crushed ice (20 g) and stirred for 15-20 min. The solid separated was filtered through a sintered funnel under suction, washed with ice-cold water $(15 \mathrm{~mL})$ and then recrystalliszed from hot ethanol or ethyl acetate to afford pure DHPMs, 2a-o. The combined aqueous filtrate was heated at $80{ }^{\circ} \mathrm{C}$ under reduced pressure $(10 \mathrm{~mm} \mathrm{Hg})$ for $4 \mathrm{~h}$ to leave behind the mixture of ILs in near complete recovery, pure enough to recycle. The recovered ionic liquid mixture was found to be equally effective for at least six recycles in the synthesis of $\mathbf{2 a}$.

\section{Spectral data for some selected DHPMs}

5-Ethoxycarbonyl-6-methyl-4-phenyl-3,4-dihydropyrimidin-2(1H)-one $(2 a)$

IR (KBr) $v_{\text {max }} / \mathrm{cm}^{-1}: 3233,2954,1730,1690,1206$, 698; ${ }^{1} \mathrm{H}$ NMR: $\delta 9.21$ (s, 1H), 7.74 (s, 1H), 7.25 (m, 5H), 5.14 (s, 1H), 3.98 (q, J 7.1 Hz, 2H), 2.25 (s, 3H), 1.09 (t, $J$ 7.1 Hz, 3H); ${ }^{13} \mathrm{C}$ NMR: $\delta$ 13.9, 17.7, 53.9, 59.1, 99.2, 126.1, 127.1, 128.3, 144.7, 148.2, 152.0, 165.2. Calc. for $\mathrm{C}_{14} \mathrm{H}_{16} \mathrm{~N}_{2} \mathrm{O}_{3}: \mathrm{C}, 64.60 ; \mathrm{H}, 6.20 ; \mathrm{N}, 10.76$. Found: C, 64.61; H, 6.18; N, 10.74. MS: $261(\mathrm{M}+1)$.

5-Ethoxycarbonyl-6-methyl-4-(4-fluorophenyl)-3,4dihydropyrimidin-2(1H)-one (2c)

IR (KBr) $v_{\max } / \mathrm{cm}^{-1}: 3240,2980,1730,1640,1230$, 1150, 790; ${ }^{1} \mathrm{H}$ NMR: $\delta 9.25$ (s, 1H), $7.77(\mathrm{~s}, 1 \mathrm{H}), 7.21$ (m, 4H), 5.15 (s, 1H), 3.99 (q, J 7.1 Hz, 2H), $2.26(\mathrm{~s}, 3 \mathrm{H})$, 1.09 (t, $J 7.1 \mathrm{~Hz}, 3 \mathrm{H}) ;{ }^{13} \mathrm{C}$ NMR: $\delta 13.9,17.8,53.6,59.5$, 123.4, 127.5, 145.2, 149.3, 151.6, 152.1, 164.8. Calc. for $\mathrm{C}_{14} \mathrm{H}_{15} \mathrm{FN}_{2} \mathrm{O}_{3}: \mathrm{C}, 60.42 ; \mathrm{H}, 5.43 ; \mathrm{N}, 10.07$. Found: C, 60.44; $\mathrm{H}, 5.42 ; \mathrm{N}, 10.10$. 
5-Ethoxycarbonyl-6-methyl-4-(4-methoxyphenyl)-3,4dihydropyrimidin-2(1H)-one $(2 f)$

IR (KBr) $v_{\max } / \mathrm{cm}^{-1}: 3206,2956,1740,1679,1245$, 1180, 1040, 875; ${ }^{1} \mathrm{H}$ NMR: $\delta 9.14(\mathrm{~s}, 1 \mathrm{H}), 7.66(\mathrm{~s}, 1 \mathrm{H})$, 6.99 (m, 4H), 5.07 (s, 1H), 3.96 (q, J 6.8 Hz, 2H), 3.70 (s, $3 \mathrm{H}), 2.23(\mathrm{~s}, 3 \mathrm{H}), 1.09$ (t, $J 6.8 \mathrm{~Hz}, 3 \mathrm{H}) ;{ }^{13} \mathrm{C}$ NMR: $\delta 14.5$, 18.2, 53.78, 55.47, 59.60, 99.9, 114.1, 127.8, 136.4, 148.3, 158.8, 165.8. Calc. for $\mathrm{C}_{15} \mathrm{H}_{18} \mathrm{~N}_{2} \mathrm{O}_{4}$ : C, 62.06; $\mathrm{H}, 6.25$; N, 9.65. Found: C, 62.04; H, 6.28; N, 9.67. MS: $291(\mathrm{M}+1)$.

5-Ethoxycarbonyl-6-methyl-4-(3,4,5-trimethoxyphenyl)3,4-dihydropyrimidin-2(1H)-thione (2o)

IR (KBr) $v_{\max } / \mathrm{cm}^{-1}: 3284,2967,1720,1632,1234$, 1140, 780; ${ }^{1} \mathrm{H}$ NMR: $\delta 10.21$ (s,1H), 9.49 (s, 1H), 7.29 (m, 2H), $5.02(\mathrm{~s}, 1 \mathrm{H}), 6.40$ (s, 2H), $3.94(\mathrm{q}, J 6.6 \mathrm{~Hz}, 2 \mathrm{H})$, 3.57 (s, 9H) 2.13 (s, 3H), $1.04(\mathrm{t}, J 7.0 \mathrm{~Hz}, 3 \mathrm{H}) ;{ }^{13} \mathrm{C}$ NMR: $\delta$ 14.9, 17.7, 54.2, 56.1, 60.1, 60.4, 101.2, 103.5, 137.1, 139.4, 145.7, 153.3, 165.4, 174.5. Calc. for $\mathrm{C}_{17} \mathrm{H}_{22} \mathrm{~N}_{2} \mathrm{O}_{5} \mathrm{~S}$ : C, 55.72; H, 6.05; N, 7.64. Found: C, 55.69; H, 6.03; N, 7.62.

\section{Conclusions}

The synergistic effect of ILs and ultrasound has been successfully demonstrated to offer an easy way for the synthesis of DHPMs in excellent yields in a single pot reaction. The milder conditions, absence of additional catalyst, high reaction rates, excellent yields, easy work up and combined use of ionic liquids and ultrasound make this procedure an improved alternative to the conventional acid/base catalyzed thermal processes and is environment friendly with minimal or no waste.

\section{Supplementary Information}

Spectral data for all synthesized DHPMs and ${ }^{13} \mathrm{C}$ NMR spectra in evidence for bonding of IL with $p$-tolualdehyde are available free of charge at http://jbcs.sbq.org.br, as PDF file.

\section{Acknowledgments}

Authors thank Dr. H. S. Patel (Sardar Patel University) for providing infrastructural and other facilities and Vaibhav Analytical Laboratory-Ahmadabad for IR facilities. A. N. Dadhania also thanks University Grant Commission, New Delhi for the award of Meritorious Student Fellowship-2008.

\section{References}

1. Biginelli, P.; Gazz. Chim. Ital. 1893, 23, 360.

2. Kappe, C. O.; Tetrahedron 1993, 49, 6937.
3. Baldwin, J. J.; Claremon, D. A.; McClure, D. E.; U.S. Patent 4 609 494, 1986; Baldwin, J. J.; Ptizenberger, S. M.; McClure, D. E.; U.S. Patent 675 321, 1987; Atwal, K. S.; U.S. Patent 4684 655, 1987; Atwal, K. S.; U.S. Patent 4684 656, 1987; Cho, H.; Ueda, M.; Shima, K.; Mizuno, A.; Hayashimatsu, M.; Ohnaka, Y.; Takeuchi, Y.; Hamaguchi, M.; Aisaka, K.; Hidaka, T.; Kawai, M.; Takeda, M.; Ishihara, T.; Funahashi, K.; Sato, F.; Morita, M.; Noguchi, T.; J. Med. Chem. 1989, 32, 2399; Atwal, K. S.; Rovnyak, G. C.; Kimball, S. D.; Floyd, D. M.; Moreland, S.; Swanson, B. N.; Gougoutas, J. Z.; Schwartz, J.; Smillie, K. M.; Malley, M. F.; J. Med. Chem. 1990, 33, 2629; Atwal, K. S.; Swanson, B. N.; Unger, S. E.; Floyd, D. M.; Moreland, S.; Hedberg, A.; O'Reilly, B. C.; J. Med. Chem. 1991, 34, 806; Nagarathnam, D.; Chiu, G.; Dhar, T.; Wong, W.; Marzabadi, M.; Gluchowski, C.; Lagu, B.; Miao, S.; PCT Int. Appl. WO 96/14846.

4. Overman, L. E.; Rabinowitz M. H.; Renhowe, P. A.; J. Am. Chem. Soc. 1995, 117, 2657; Snider, B. B.; Shi, Z.; J. Org. Chem. 1993, 58, 3828.

5. Atwal, K. S.; O’Reilly, B. C.; Gougoutas, J. Z.; Malley, M. F.; Heterocycles 1987, 26, 1189; Atwal, K. S.; Rovnyak, G. C.; O'Reilly, B. C.; Schwartz, J.; J. Org. Chem. 1989, 54, 5898; Barluenga, J.; Tomas, M.; Rubio, V.; Gotor, V.; J. Chem. Soc., Chem. Commun. 1979, 16, 675; Barluenga, J.; Tomas, M.; Ballesteros, A.; Lopez, L. A.; Tetrahedron Lett. 1989, 30, 4573; Wipf, P.; Cunningham, A.; Tetrahedron Lett. 1995, 36, 7819.

6. Hu, E. H.; Sidler, D. R.; Dolling, U.; J. Org. Chem. 1998, 63, 3454.

7. Kappe, C. O.; Falsone, S. F.; Synlett 1998, 7, 718.

8. Polshettiwar, V.; Varma, R. S.; Tetrahedron Lett. 2007, 48, 7343; Banik, B. K.; Reddy, A. T.; Datta, A.; Mukhopadhyay, C.; Tetrahedron Lett. 2007, 48, 7392; Debache, A.; Boumoud, B.; Amimour, M.; Belfaitah, A.; Rhouati, S.; Carboni, B.; Tetrahedron Lett. 2006, 47, 5697; Ahmed, N.; van Lier J. E. Tetrahedron Lett. 2007, 48, 5407; Bigi, F.; Carloni, S.; Frullanti, B.; Maggi, R.; Sartori, G.; Tetrahedron Lett. 1999, 40, 3465; Radha Rani, V.; Srinivas, N.; Radha Krishnan, M.; Kulkarni, S. J.; Raghavan, K. V.; Green Chem. 2001, 3, 305; Lu, J.; Ma, H.; Synlett 2000, 1, 63; Lu, J.; Bai, Y.; Wang, Z.; Yang, B.; Ma, H.; Tetrahedron Lett. 2000, 41, 9075; Ma, Y.; Qian, C.; Wang, L.; Yang, M.; J. Org. Chem. 2000, 65, 3864; Ranu, B. C.; Hajra, A.; Jana, U.; J. Org. Chem. 2000, 65, 6270.

9. Gupta, R.; Gupta, A. K.; Paul, S.; Kachroo, P. L.; Indian J. Chem. B 1995, 34, 151; Kappe, C. O.; Kumar, D.; Varma, R. S.; Synthesis 1999, 10, 1799; Yadav, J. S.; Reddy, B. V. S.; Reddy, E. J.; Ramalingam, T.; J. Chem. Res. (S) 2000, 354; Stefani, H. A.; Gatti, P. M.; Synth. Commun. 2000, 30, 2165; Kidwai, M.; Saxena, S.; Mohan, R.; Venkataramanan, R.; J. Chem. Soc., Perkin Trans. 1 2002, 1939.

10. Yadav, J. S.; Reddy, B. V. S.; Reddy, K. B.; Raj, K. S.; Prasad, A. R.; J. Chem. Soc., Perkin Trans. 1 2001, 1939; Li, J. T.; Han, J. F.; Yang, J. H.; Li, T. S.; Ultrason. Sonochem. 2003, 10, 119. 
11. Welton, T.; Chem. Rev. 1999, 99, 2071; Wasserscheid, P.; Keim, W.; Angew. Chem., Int. Ed. 2000, 39, 377.

12. Palimkar, S. S.; Siddiqui S. A.; Daniel T.; Lahoti R. J.; Srinivasan K. V.; J. Org. Chem. 2003, 68, 9371.

13. Earle, M. J.; Mccormac, P. B.; Seddon, K. R.; Chem. Commun. 1998, 20, 2245; Yang, S. D.; Wu, L. Y.; Liang, Y. M.; J. Mol. Catal. A: Chem. 2007, 268, 107.

14. Luche, J. L.; Synthetic Organic Sonochemistry, Plenum: New York, 1998; Mason, T. J.; Peer, D.; Practical Sonochemistry, $2^{\text {nd }}$ ed., Ellis Horwood; London, 2002.

15. Cravotto G.; Cintas P.; Chem. Soc. Rev. 2006, 35, 180.
16. Li, J.; Peng, Y.; Song, G.; Catal. Lett. 2005, 102, 3.

17. Fu, N.; Yuan, Y.; Cao, Z.; Wang, S.; Wang, J.; Peppe, C.; Tetrahedron 2002, 58, 4801.

18. Chari, M. A.; Shobha, D.; Kumar, T. K.; Dubey, P. K.; Arkivoc 2005, $x v, 74$.

19. Paraskar, S.; Dewkar, G. K.; Sudalai, A.; Tetrahedron lett. 2003, 44, 3305 .

20. Reddy, C. V.; Mahesh, M.; Raju, P. V. K.; Babu, T. R.; Reddy, V. V. N.; Tetrahedron Lett. 2002, 43, 2657.

21. Gholap, R.; Venkatesan, K.; Daniel, T.; Lahoti, R. J.; Srinivasan, K. V.; Green Chem. 2004, 6, 147. 


\title{
A Convenient and Efficient Protocol for the One Pot Synthesis of 3,4-Dihydropyrimidin-2-(1H)-ones Catalyzed by Ionic Liquids under Ultrasound Irradiation
}

\author{
Abhishek N. Dadhania, Vaibhav K. Patel and Dipak K. Raval* \\ Department of Chemistry, Sardar Patel University, Vallabh Vidyanagar, 388 120, Gujarat, India
}

Spectral data for all synthesized DHPMs

5-Ethoxycarbonyl-6-methyl-4-(4-nitrophenyl)-3,4dihydropyrimidin-2(1H)-one $(2 \boldsymbol{b})$

IR (KBr) $v_{\max } / \mathrm{cm}^{-1}: 3224,2950,1745,1670,1510$, 1340, 1125, 780; ${ }^{1} \mathrm{H}$ NMR: $\delta 9.37(\mathrm{~s}, 1 \mathrm{H}), 8.20(\mathrm{~d}, 2 \mathrm{H})$, $7.91(\mathrm{~s}, 1 \mathrm{H}), 7.50(\mathrm{~d}, 2 \mathrm{H}), 5.27(\mathrm{~s}, 1 \mathrm{H}), 3.98(\mathrm{q}, J 7.1$ $\mathrm{Hz}, 2 \mathrm{H}), 2.27$ (s, 3H), 1.09 (t, $J 7.1 \mathrm{~Hz}, 3 \mathrm{H}) ;{ }^{13} \mathrm{C}$ NMR: $\delta$ 13.9, 17.8, 53.6, 59.3, 123.7, 127.5, 146.6, 149.3, 151.7, 151.9, 164.9. Calc. for $\mathrm{C}_{14} \mathrm{H}_{15} \mathrm{~N}_{3} \mathrm{O}_{5}: \mathrm{C}, 55.08 ; \mathrm{H}, 4.95 ; \mathrm{N}$, 13.76. Found: C, 55.05; H, 4.97; N, 13.74 .

5-Ethoxycarbonyl-6-methyl-4-(3-chlorophenyl)-3,4dihydropyrimidin-2(1H)-one $(2 \mathrm{~d})$

IR (KBr) $v_{\text {max }} / \mathrm{cm}^{-1}: 3254,2966,1738,1669,1170,1096$, 759; ${ }^{1} \mathrm{H}$ NMR: $\delta 9.24(\mathrm{~s}, 1 \mathrm{H}), 7.77(\mathrm{~s}, 1 \mathrm{H}), 7.26(\mathrm{~m}, 4 \mathrm{H})$, 5.14 (s, 1H), 3.98 (q, J $7.1 \mathrm{~Hz}, 2 \mathrm{H}), 2.25$ (s, 3H), 1.09 (t, $J 7.1 \mathrm{~Hz}, 3 \mathrm{H}) ;{ }^{13} \mathrm{C}$ NMR: $\delta$ 14.0, 17.8, 53.6, 59.3, 98.7, 124.9, 126.2, 127.2, 130.4, 132.9, 147.2, 148.9, 151.9, 165.2. Calc. for $\mathrm{C}_{14} \mathrm{H}_{15} \mathrm{ClN}_{2} \mathrm{O}_{3}$ : C, 57.05; H, 5.13; N, 9.50. Found: C, 57.08; H, 5.16; N, 9.48.

5-Ethoxycarbonyl-6-methyl-4-(4-methylphenyl)-3,4dihydropyrimidin-2(1H)-one (2e)

$\operatorname{IR}(\mathrm{KBr}) v_{\text {max }} / \mathrm{cm}^{-1}: 3260,2980,1720,1635,1248,1120$, 775; ${ }^{1} \mathrm{H}$ NMR: $\delta 9.15(\mathrm{~s}, 1 \mathrm{H}), 7.80(\mathrm{~s}, 1 \mathrm{H}), 7.10(\mathrm{~s}, 4 \mathrm{H})$, 5.09 (s, 1H), $3.96(\mathrm{q}, J 7.1 \mathrm{~Hz}, 2 \mathrm{H}), 2.23(\mathrm{~s}, 3 \mathrm{H}), 1.08$ (t, $J$ J.1 Hz, 3H); ${ }^{13} \mathrm{C}$ NMR: $\delta 14.1,17.7,20.6,53.7,59.1,99.4$, $126.1,128.8,136.3,141.7,148.2,152.2,165.2$. Calc. for $\mathrm{C}_{15} \mathrm{H}_{18} \mathrm{~N}_{2} \mathrm{O}_{3}: \mathrm{C}, 65.68 ; \mathrm{H}, 6.61 ; \mathrm{N}, 10.21$. Found: C, 65.64; $\mathrm{H}, 6.59 ; \mathrm{N}, 10.23$.

*e-mail: dipanalka@yahoo.com
5-Ethoxycarbonyl-6-methyl-4-(2-furyl)-3,4-dihydropyrimidin-2(1H)-one $(2 \mathrm{~g})$

IR $(\mathrm{KBr}) v_{\max } / \mathrm{cm}^{-1}: 3234,2918,1727,1648,1234$, 1113; ${ }^{1} \mathrm{H}$ NMR: $\delta 9.24(\mathrm{~s}, 1 \mathrm{H}), 7.75(\mathrm{~s}, 1 \mathrm{H}), 7.54(\mathrm{~s}, 1 \mathrm{H})$, 6.34 (s, 1H), 6.08 (s, 1H), 5.19 (s, 1H), 4.01 (q, J $6.9 \mathrm{~Hz}$, 2H), 2.22 (s, 3H), 1.12 (t, $J 6.9 \mathrm{~Hz}, 3 \mathrm{H}) ;{ }^{13} \mathrm{C}$ NMR: $\delta 14.1$, 17.7, 47.8, 59.1, 96.8, 105.2, 110.3, 142.3, 149.2, 152.2, 155.9, 165.2. Calc. for $\mathrm{C}_{12} \mathrm{H}_{14} \mathrm{~N}_{2} \mathrm{O}_{4}$ : C, 57.59; H, 5.64; $\mathrm{N}, 11.19$. Found: C, 57.55; H, 5.62; N, 11.21.

5-Ethoxycarbonyl-6-methyl-4-(2-chlorophenyl)-3,4dihydropyrimidin-2(1H)-one $(\mathbf{2 h})$

IR (KBr) $v_{\text {max }} / \mathrm{cm}^{-1}: 3109,2948,1725,1698,1177,1089$, 750; ${ }^{1} \mathrm{H}$ NMR: $\delta 9.25(\mathrm{~s}, 1 \mathrm{H}), 7.70(\mathrm{~s}, 1 \mathrm{H}), 7.33(\mathrm{~m}, 4 \mathrm{H})$, $5.61(\mathrm{~s}, 1 \mathrm{H}), 3.87(\mathrm{q}, J 6.9 \mathrm{~Hz}, 2 \mathrm{H}), 2.28(\mathrm{~s}, 3 \mathrm{H}), 0.98(\mathrm{t}$, $J 6.9 \mathrm{~Hz}, 3 \mathrm{H}) ;{ }^{13} \mathrm{C}$ NMR: $\delta 13.9,17.7,51.6,59.1,98.2,127.7$, 128.8, 129.1, 129.4, 131.8, 141.7, 149.2, 151.4, 165.0. Calc. for $\mathrm{C}_{14} \mathrm{H}_{15} \mathrm{ClN}_{2} \mathrm{O}_{3}: \mathrm{C}, 57.05 ; \mathrm{H}, 5.13 ; \mathrm{N}, 9.50$. Found: C, $57.08 ; \mathrm{H}, 5.15 ; \mathrm{N}, 9.53$.

5-Ethoxycarbonyl-6-methyl-4-(4-hydroxyphenyl)-3,4dihydropyrimidin-2(1H)-one (2i)

IR (KBr) $v_{\text {max }} / \mathrm{cm}^{-1}: 3358,3219,2930,1731,1678,1171$, 819; ${ }^{1} \mathrm{H}$ NMR: $\delta 9.34(\mathrm{~s}, 1 \mathrm{H}), 9.10(\mathrm{~s}, 1 \mathrm{H}), 7.64(\mathrm{~s}, 1 \mathrm{H})$, $6.84(\mathrm{~m}, 4 \mathrm{H}), 5.02(\mathrm{~s}, 1 \mathrm{H}), 3.96(\mathrm{q}, J 7.0 \mathrm{~Hz}, 2 \mathrm{H}), 2.21$ (s, $3 \mathrm{H}), 1.08$ (t, $J 7.0 \mathrm{~Hz}, 3 \mathrm{H}$ ); ${ }^{13} \mathrm{C}$ NMR: $\delta$ 13.7, 17.45, 54.4, 59.2, 101.1, 115.0, 127.7, 133.8, 146.9, 153.0, 156.8, 165.4 . Calc. for $\mathrm{C}_{14} \mathrm{H}_{16} \mathrm{~N}_{2} \mathrm{O}_{4}: \mathrm{C}, 60.86 ; \mathrm{H}, 5.84 ; \mathrm{N}, 10.14$. Found: C, $60.84 ; \mathrm{H}, 5.86$; N, 10.16 .

5-Ethoxycarbonyl-6-methyl-4-(3,4,5-trimethoxyphenyl)3,4-dihydropyrimidin-2(1H)-one (2j)

IR (KBr) $v_{\text {max }} / \mathrm{cm}^{-1}: 3215,2922,1732,1676,1248,1126$, 821; ' ${ }^{\mathrm{H}} \mathrm{NMR}$ : $\delta 9.23$ (s,1H), 7.75 (s, 1H), 6.53 (s, 2H), 
$5.13(\mathrm{~s}, 1 \mathrm{H}), 4.02(\mathrm{q}, J 6.6 \mathrm{~Hz}, 2 \mathrm{H}), 3.72(\mathrm{~s}, 9 \mathrm{H}), 2.25$ (s, $3 \mathrm{H}), 1.13(\mathrm{t}, J 7.0 \mathrm{~Hz}, 3 \mathrm{H}) ;{ }^{13} \mathrm{C} \mathrm{NMR}: \delta 14.2,17.8,54.1$, 56.0, 59.4, 60.1, 99.3, 104.3, 140.6, 148.5, 152.5, 152.9, 165.4. Calc. for $\mathrm{C}_{17} \mathrm{H}_{22} \mathrm{~N}_{2} \mathrm{O}_{6}$ : C, 58.28; H, 6.33; N, 8.00. Found: C, 58.24; H, 6.30; N, 8.03.

5-Ethoxycarbonyl-6-methyl-4-(4-hydroxy-3-methoxyphenyl)-3,4-dihydropyrimidin-2(1H)-one (2k)

$\operatorname{IR}(\mathrm{KBr}) v_{\max } / \mathrm{cm}^{-1}: 3384,3238,2994,1726,1642,1210$, 1140, 756; ${ }^{1} \mathrm{H}$ NMR: $\delta 9.35$ (s,1H), 9.10 (s, 1H), 7.68 (s, 1H), 7.32 (m,3H), 6.10 (s, 1H), 4.12 (q, J7.2 Hz, 2H), 3.45 $(\mathrm{s}, 3 \mathrm{H}), 2.32(\mathrm{~s}, 3 \mathrm{H}), 1.10(\mathrm{t}, J 7.2 \mathrm{~Hz}, 3 \mathrm{H}) ;{ }^{13} \mathrm{C} \mathrm{NMR}: \delta$ 13.6, 18.8, 54.4, 61.7, 101.7, 113.54, 127.8, 128.9, 139.6, 141.8, 146.4, 148.3, 158.8, 165.8. Calc. for $\mathrm{C}_{15} \mathrm{H}_{18} \mathrm{~N}_{2} \mathrm{O}_{5}$ : C, 58.82; H, 5.92; N, 9.15. Found: C, 58.79; H, 5.93; N, 9.12 .

5-Ethoxycarbonyl-6-methyl-4-(2-thienyl)-3,4-dihydropyrimidin-2(1H)-one $(2 \mathrm{l})$

$\operatorname{IR}(\mathrm{KBr}) v_{\max } / \mathrm{cm}^{-1}: 3228,2954,1734,1664,1242,1127$, 786; ${ }^{1} \mathrm{H}$ NMR: $\delta 9.31(\mathrm{~s}, 1 \mathrm{H}), 7.88(\mathrm{~s}, 1 \mathrm{H}), 7.35(\mathrm{~d}, 1 \mathrm{H})$, $6.90(\mathrm{~m}, 2 \mathrm{H}), 5.39$ (s, 1H), 4.05 (q, J 7.1 Hz, 2H), 2.20 (s, $3 \mathrm{H}), 1.15(\mathrm{t}, J 7.1 \mathrm{~Hz}, 3 \mathrm{H}) ;{ }^{13} \mathrm{C}$ NMR: $\delta 14.2,17.7,49.9$,
59.3, 99.8, 124.1, 124.9, 126.3, 148.7, 148.9, 152.3, 165.0. Calc. for $\mathrm{C}_{12} \mathrm{H}_{14} \mathrm{~N}_{2} \mathrm{O}_{3} \mathrm{~S}: \mathrm{C}, 54.12 ; \mathrm{H}, 5.30 ; \mathrm{N}, 10.52$. Found: C, 54.15; H, 5.34; N, 10.54 .

5-Ethoxycarbonyl-6-methyl-4-phenyl-3,4-dihydropyrimidin-2(1H)-thione $(\mathbf{2 m})$

IR (KBr) $v_{\max } / \mathrm{cm}^{-1}: 3200,2956,1720,1678,1180,1097$, 694; ${ }^{1} \mathrm{H}$ NMR: $\delta 10.32$ (s,1H), 9.64 (s, 1H), 7.27 (m, 5H), $5.15(\mathrm{~d}, 1 \mathrm{H}), 4.01(\mathrm{q}, J 7.0 \mathrm{~Hz}, 2 \mathrm{H}), 2.27(\mathrm{~s}, 3 \mathrm{H}), 1.09$ (t, $J 7.0 \mathrm{~Hz}, 3 \mathrm{H}) ;{ }^{13} \mathrm{C}$ NMR: $\delta$ 14.4, 17.6, 54.4, 60.0, 101.1, 126.8, 128.1, 129.2, 140.4, 143.9, 153.7, 165.5. Calc. for $\mathrm{C}_{14} \mathrm{H}_{16} \mathrm{~N}_{2} \mathrm{O}_{2} \mathrm{~S}: \mathrm{C}, 60.85 ; \mathrm{H}, 5.84 ; \mathrm{N}, 10.14$. Found: C, 60.84; $\mathrm{H}, 5.80$; N, 10.16 .

5-Ethoxycarbonyl-6-methyl-4-(4-methoxyphenyl)-3,4dihydropyrimidin-2(1H)-thione $\mathbf{( 2 n )}$

IR (KBr) $v_{\max } / \mathrm{cm}^{-1}: 3088,2933,1730,1687,1247,1175$, 944; ${ }^{1} \mathrm{H}$ NMR: $\delta 10.28$ (s,1H), 9.59 (s, 1H), 7.01 (m, 4H), 5.10 (s, 1H), 3.98 (q, J 7.0 Hz, 2H), 3.70 (s, 3H), 2.27 (s, 3H), 1.09 (t, J 7.0 Hz, 3H); ${ }^{13} \mathrm{C}$ NMR: $\delta$ 14.1, 17.6, 53.9, 55.2, 59.6, 101.2, 113.7, 127.5, 135.3, 144.7, 158.2, 165.2, 174.2. Calc. for $\mathrm{C}_{15} \mathrm{H}_{18} \mathrm{~N}_{2} \mathrm{O}_{3} \mathrm{~S}: \mathrm{C}, 58.80 ; \mathrm{H}, 5.92 ; \mathrm{N}, 9.14$. Found: C, 58.78; H, 5.95; N, 9.11.

Copies of ${ }^{13} \mathrm{C} N \mathrm{NM}$ spectra in evidence for bonding of IL with p-tolualdehyde
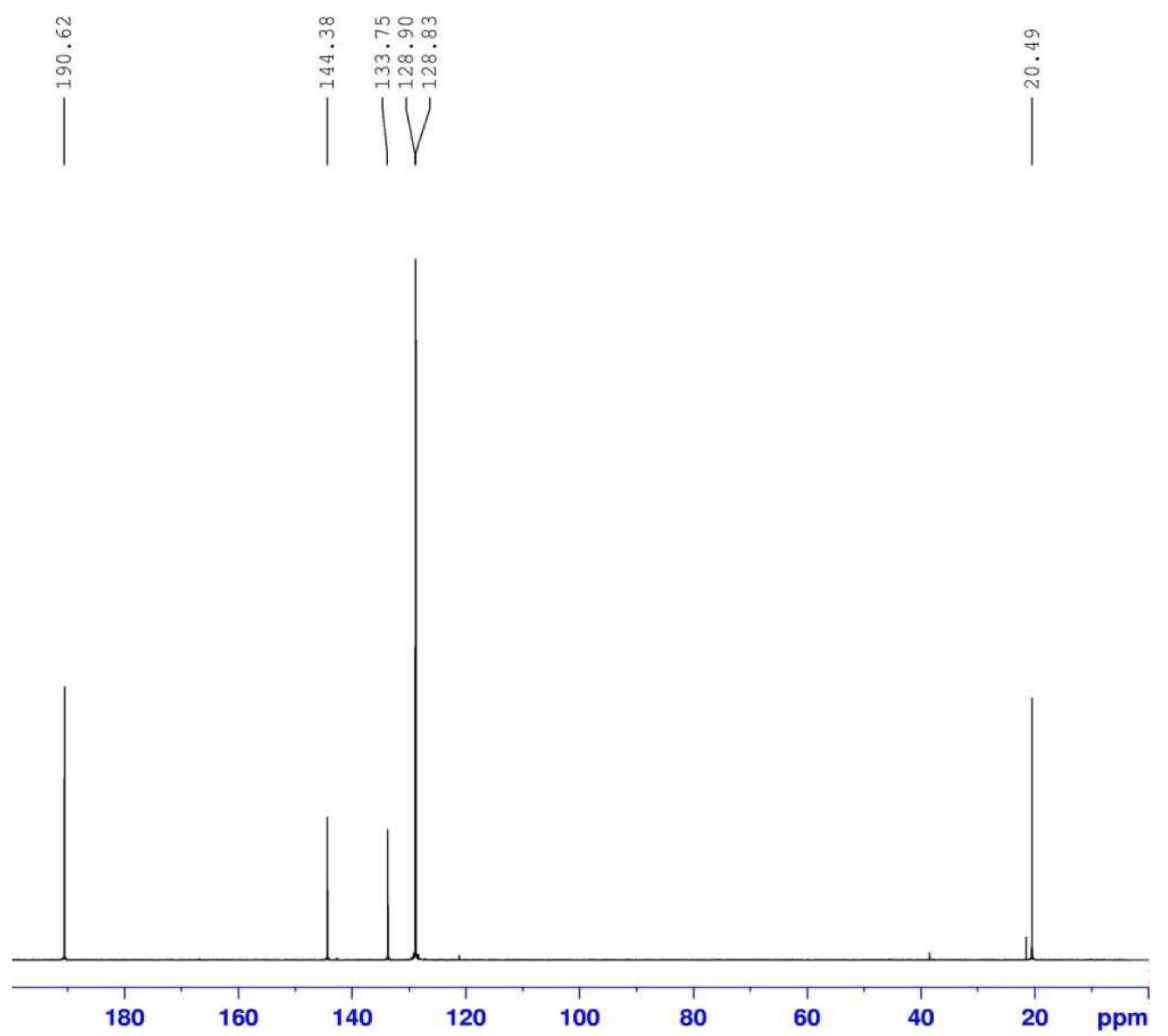

Figure S1. ${ }^{13} \mathrm{C}$ NMR spectrum of neat $p$-tolualdehyde. 

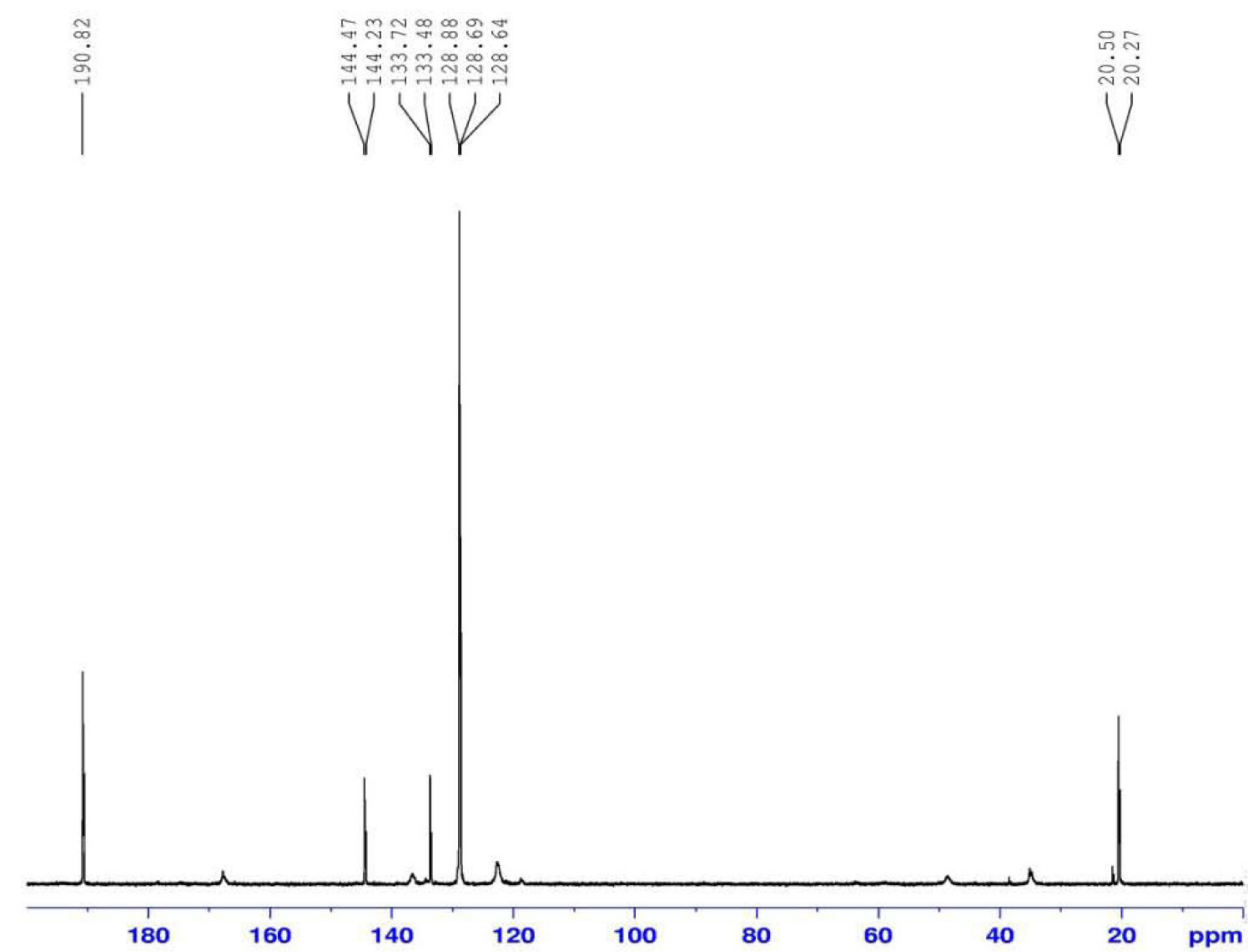

Figure S2. ${ }^{13} \mathrm{C}$ NMR spectrum of $p$-tolualdehyde $+[\mathrm{cmmim}]\left[\mathrm{BF}_{4}\right]$.
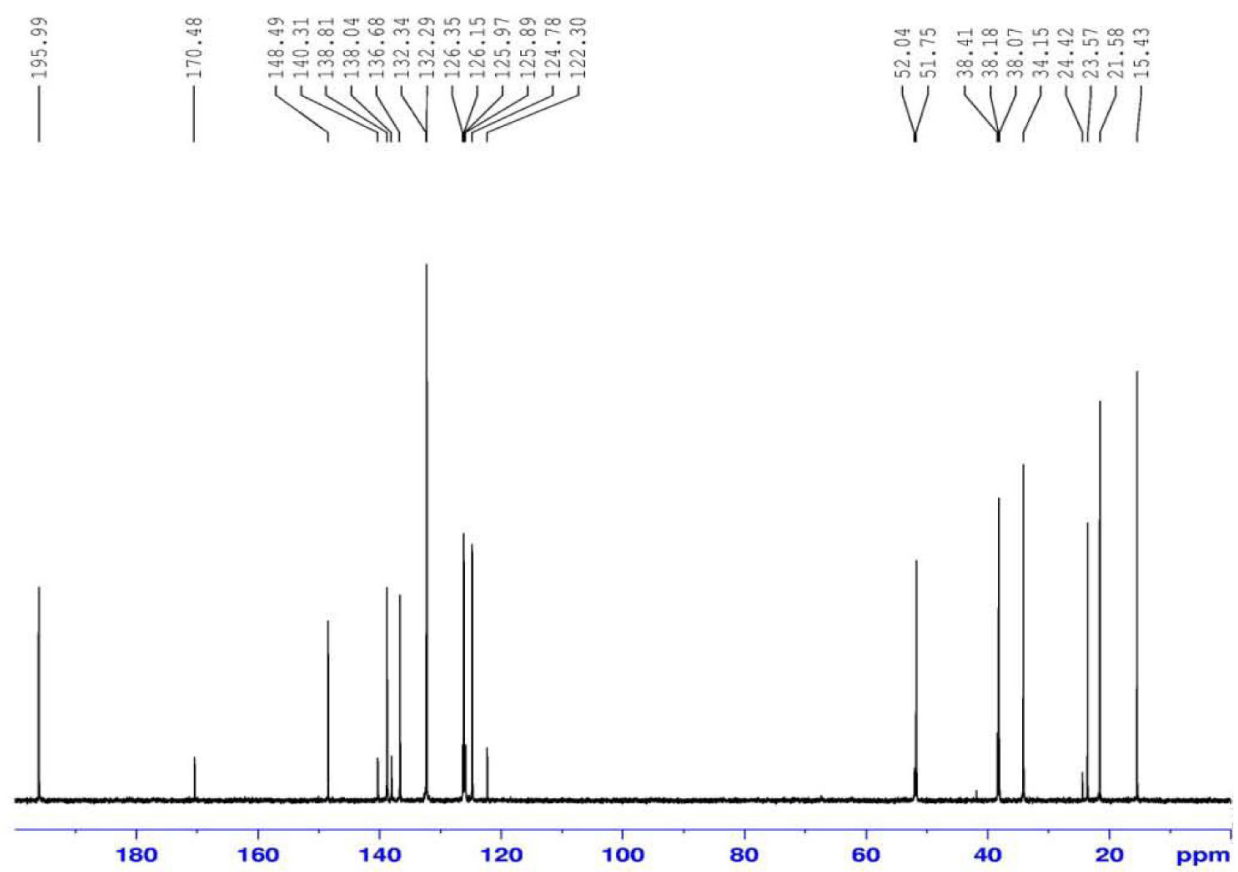

Figure S3. ${ }^{13} \mathrm{C}$ NMR spectrum of $p$-tolualdehyde $+[\mathrm{cmmim}]\left[\mathrm{BF}_{4}\right]+[\mathrm{bmim}]\left[\mathrm{BF}_{4}\right]$. 